\title{
Disturbance-induced 'spill-in' of Caribbean spiny lobster to marine reserves
}

\author{
David B. Eggleston ${ }^{1,2, *}$, Darren M. Parsons ${ }^{1,3}$ \\ ${ }^{1}$ North Carolina State University, Department of Marine, Earth and Atmospheric Sciences, Raleigh, \\ North Carolina 27695-8208, USA \\ ${ }^{2}$ North Carolina State University, Center for Marine Sciences and Technology, 303 College Circle, Morehead City, \\ North Carolina 28557, USA \\ ${ }^{3}$ National Institute of Water and Atmospheric Research, Private Bag 99940, Auckland, New Zealand
}

\begin{abstract}
Marine reserves have the potential to enhance fisheries productivity by increasing total spawning potential or by spillover, the migration of juveniles and adults from reserves to non-reserve areas. Spillover has been the focus of many studies and has been an important argument in promoting the benefits of marine reserves to gain public support. Few studies, however, have examined mechanisms for colonization or migrations into marine reserves. The present study provides direct field evidence that disturbance from a sport diving fishery can elevate the abundance of Caribbean spiny lobster Panulirus argus in nearby marine reserves - particularly in reserves containing relatively high densities of non-disturbed lobsters - presumably through conspecific attraction where lobsters follow chemical cues to undisturbed sites in marine reserves. Population redistribution following fishery disturbance has implications for marine reserve design and application. For example, risk-averse fishery management strategies might locate reserves adjacent to intensely fished areas to enhance spill-in of mobile species.
\end{abstract}

KEY WORDS: Animal behavior - Caribbean spiny lobster · Disturbance - Fisheries management • Sociality · Marine protected areas · Marine reserves $\cdot$ Predation $\cdot$ Spill-in $\cdot$ Spillover $\cdot$ Sport divers

\section{INTRODUCTION}

Marine no-take reserves - areas closed to fishing and other extractive activities - are tools used to protect and rebuild many of the world's highly targeted fishery species (NRC 2001, Sobel \& Dahlgren 2004). A major expectation of reserves, and the prevailing paradigm of reserves from a fisheries perspective over the past decade, is that organisms, over time, will enhance adjacent, non-reserve areas through 2 mechanisms: (1) net export of eggs and larvae from reserves and subsequent settlement, growth and recruitment to the fishery, and (2) spillover. While spillover was originally defined as the density dependent movement of juveniles and adults from reserves to adjacent fished areas (PDT 1990), it is often interpreted as the net movement of animals out of reserves, which is the interpretation used for the present study. Spillover from marine reserves may potentially improve adjacent fishery yields (Russ et al. 2004, Alcala et al. 2005) and as such has been an important argument in promoting the benefits of marine reserves to gain support from local recreational and commercial fishermen, and has been the focus of a significant amount of research on the function of reserves in marine ecosystems (review by Sobel \& Dahlgren 2004).

However, this growing body of research on reserve function lacks information about animals that disperse into reserves. For example, most studies that have assessed the effects of spatial location, life history stage and dispersal ability on the efficacy of marine reserves have assumed random diffusion of animals into a reserve, and have focused nearly entirely on spillover via general migration of mobile animals, 
density dependent movements away from areas of lower resource availability, or ontogenetic habitat shifts (e.g. Gerber et al. 2005 and references therein). In the present study, we examine marine reserve function by considering the behavioral mechanisms underlying immigration to reserves and its ecological and management consequences. The Caribbean spiny lobster Panulirus argus, which is actively hunted by sport divers in the Florida Keys, USA, is used as an example of disturbance-induced immigration to marine reserves.

Caribbean spiny lobsters support important recreational and commercial fisheries throughout their range (Lipcius \& Eggleston 2000). Spiny lobsters are highly gregarious, aggregating in crevices and beneath sponges during the day (Herrnkind et al. 1975, Eggleston \& Lipcius 1992), and foraging on gastropods, chitons and bivalves in nearby seagrass beds and hard bottom habitats at night (Cox et al. 1997). As spiny lobsters return to their dens from nocturnal foraging, or exhibit larger scale ontogenetic habitat shifts, they use the smell of conspecifics to form migrating queues (i.e. single-file lines), and further use the smell of conspecifics already inhabiting shelters as a type of 'guide effect' to find high quality shelter more quickly than in the absence of conspecific odors (Childress \& Herrnkind 2001). The attractive odor is volumedependent (i.e. dependent on the size of the individual or group) and released by conspecifics around dawn (Ratchford \& Eggleston 1998, 2000).

Recreational sport divers exploit the gregarious nature of lobsters by targeting dens with high densities of lobsters, and coercing them into hand-nets with 'tickle sticks' (Eggleston et al. 2003). Recreational fishing effort for spiny lobsters in the Florida Keys is among the most intense recreational fisheries in the world (Eggleston et al. 2008). Fishing effort peaks during a $2 \mathrm{~d}$ mini-season for sport divers during the last week of July before the fishery opens to commercial and recreational fishers at the beginning of August. During this 2 d recreational fishery, 80-90\% of legal sized lobsters present in targeted areas are removed (Eggleston et al. 2003, 2008) and up to $27 \%$ of the remaining population of legal and sublegal lobsters may become visibly injured from interaction with sport divers (Parsons \& Eggleston 2005). Lobster injury can result from either (1) an unsuccessful capture attempt, or (2) a successful capture and release of a sub-legal lobster. These injuries are detrimental to lobsters by reducing their growth (Davis 1981), causing direct mortality (Parsons \& Eggleston 2005) and increasing exposure to predation by emigration from daytime shelters (Parsons \& Eggleston 2006). Furthermore, the ability to attract other lobsters is eliminated when a lobster becomes injured (Parsons \& Eggleston 2005).
During underwater surveys of spiny lobsters in marine reserves and fished areas of the lower Florida Keys during summer 2004, we observed that the density of spiny lobster decreased by $\sim 50 \%$ in fished areas from before to after the $2 \mathrm{~d}$ sport diver mini-season, yet increased $\sim 3$-fold in the relatively large and nearby Western Sambo marine reserve which contained high densities of relatively large lobsters (Fig. 1). The 2 most parsimonious explanations for this are: (1) sheer chance from low sample size and high variation in the data, and (2) a rapid migration of lobster into this large marine reserve in the Florida Keys National Marine Sanctuary (FKNMS). We hypothesized that the density of lobsters would decline in fished areas after the $2 \mathrm{~d}$ mini-season, but increase in marine reserves in a density-dependent manner with the greatest increases occurring in reserves containing the greatest density of non-disturbed lobsters. The mechanisms underlying this hypothesis were that lobsters disturbed by divers in fished areas would migrate from the shelters where they were disturbed (Parsons \& Eggleston 2005, 2006) and follow queues of lobsters from non-disturbed marine reserves back to their shelters (Herrnkind et al. 1975), or migrate into marine reserves by following a gradient of attractant odors emitted from relatively high densities of uninjured lobsters in reserves (Ratchford \& Eggleston 1998, Childress \& Herrnkind 2001, Parsons \& Eggleston 2005). We tested this hypothesis by quantifying lobster densities inside and outside of replicate coral reef marine reserves before versus after fishing. Marine reserves provide a unique experimental opportunity to test the effects of large-scale disturbances, such as fishing, on the abundance, diversity and behaviour of marine organisms at relatively large spatial scales. Lobster fishing is prohibited in marine reserves that are part of the FKNMS.

\section{MATERIALS AND METHODS}

To test if lobsters migrate into reserves after disturbance, and if immigration increases with the density of conspecifics within a reserve, we quantified the density of spiny lobster before and after the $2 \mathrm{~d}$ sport diver mini-season in 5 marine reserves and 5 adjacent fished areas on the Atlantic Ocean side of the Florida Keys (Fig. 1) in late July to early August 2005 and 2007. The marine reserves are closed to fishing and range in area from 30 ha (e.g. Rock Key) to 3000 ha (e.g. Western Sambo) (Fig. 1). Although reserve area varies widely, inferences concerning lobster density in marine reserves and adjacent fished areas in the present study were restricted to the spur and groove fore-reef habitat, which typically contains the highest densities of lobsters (Cox \& Hunt 2005). The linear distance (km) of 


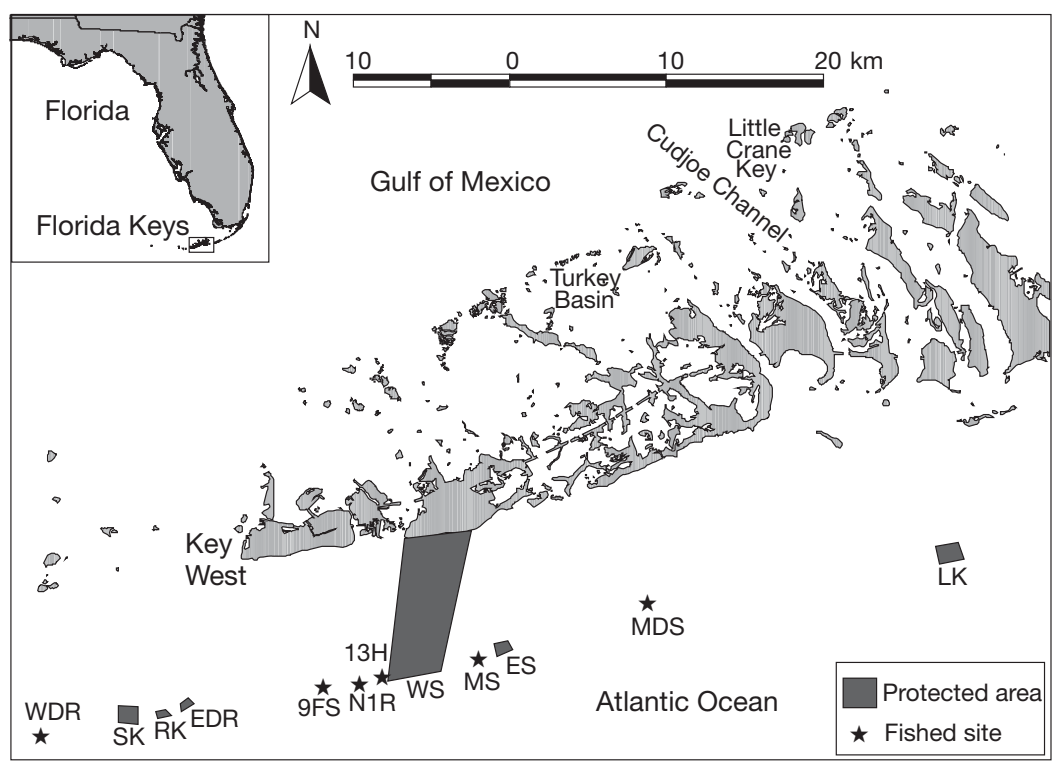

Fig. 1. Sampling sites on the southern (Atlantic Ocean) side of the lower Florida Keys. WDR = Western Dry Rocks, SK = Sand Key, RK = Rock Key, EDR = Eastern Dry Rocks, 9FS = Nine Foot Stake, N1R $=$ Number 1 Marker Reef, $13 \mathrm{H}=13$ Foot Hump, WS $=$ Western Sambo, MS = Middle Sambo, ES = Eastern Sambo, MDS = Maryland Shoal, and LK = Looe Key. Lobster surveys were generally conducted within the grooves of the spur-and-groove fore-reef and at least $200 \mathrm{~m}$ within the boundaries the marine reserves

reef location, the research boat was anchored as close as possible to the middle of a grid cell using a differential GPS, and 3 divers surveyed areas that were along headings that varied by $30^{\circ}$ from each other and radiated from offshore to inshore, typically along grooves of the fore reef. Each diver swam along the same tract before and after the fishing season so that observations could be paired for subsequent statistical analyses. Surveys consisted of $10 \mathrm{~min}$ timed searches for spiny lobsters when divers were over suitable lobster habitat, such as crevices in coral reefs and hardbottom areas. The clock was turned off when it was necessary to traverse a large area of sand or seagrass. Once the survey was completed, divers surfaced and visually estimated the distance travelled from the boat. The area searched by an individual diver per survey averaged $253 \mathrm{~m}^{-2}(\mathrm{SE}=27.9, \mathrm{n}=56)$. In a related study, we assessed the accuracy of visual estimates of distance travelled and area searched during 10 min sur-

fore-reef varies by $\sim 2$-fold among marine reserves. For example, using digitized maps of the reef tract and GIS ArcView software, we determined that the linear distance of the fore-reef for Western Sambo and Looe Key (1.46 km and $1.31 \mathrm{~km}$, respectively) was approximately twice that of the remaining reserves (e.g. range = $0.73 \mathrm{~km}$ for Rock Key to $1.09 \mathrm{~km}$ for Sand Key). Thus, we allocated twice the sampling effort to Looe Key and Western Sambo compared to all other reserves and fished areas.

Lobster surveys were conducted by scuba divers during the day (09:00 to 16:00 h) when water visibility exceeded $6 \mathrm{~m}$. Spiny lobster carapace length (CL) in $\mathrm{cm}$ was estimated by comparing a lobster to a ruler attached perpendicularly to the far end of a $70 \mathrm{~cm}$ rod held out by a diver. This device helped avoid underwater magnification problems in estimating lobster size, and was used in estimating the $2 \mathrm{~m}$ width of a search area during lobster surveys in offshore coral reefs. Lobster CL was estimated to the nearest $1 \mathrm{~cm}$. For consistency, the same experienced group of 6 divers conducted all surveys. To sample lobsters, a grid system of $1 \times 1 \mathrm{~km}$ cells was superimposed over the reef at each of the 6 reserves ( 5 in 2007) and 6 fished areas and then 1 to 2 cells were randomly chosen to sample depending upon the reserve ( 2 cells at Western Sambo and Looe Key, Looe Key sampled in 2005 only). At each offshore veys, and found that although divers tended to overestimate the distance travelled by an average of $4.5 \mathrm{~m}$, estimates were not significantly different from known distances as measured with a differential GPS on a research boat (Eggleston et al. 2004). The surveys in the present study were conducted over a $3 \mathrm{~d}$ period just prior to and immediately after the $2 \mathrm{~d}$ sport diver mini-season. The initial response variable was the density of spiny lobster (no. $\mathrm{m}^{-2}$ ).

A 1-tailed $t$-test determined if the change in mean density of spiny lobsters from before to after the fishing season was significantly different from 0 for reefs open or closed to fishing. Using linear and non-linear regression models, we tested the relationship between the change in density of all lobsters and legal-sized lobsters from before to after the $2 \mathrm{~d}$ mini-season in reserves.

\section{RESULTS}

The mean density of legal-sized lobsters was similar in fished areas and marine reserves just prior to the $2 \mathrm{~d}$ sport diver mini-season in 2005 (fished areas: mean lobster density $=0.005 \mathrm{~m}^{-2}, \mathrm{SE}=0.002, \mathrm{n}=6$; marine reserves: mean lobster density $=0.006 \mathrm{~m}^{-2}, \mathrm{SE}=0.002$, $\mathrm{n}=6$ ). The total number of lobsters observed in marine 
Table 1. Panulirus argus. Number and mean density (lobsters $\mathrm{m}^{-2}$ ) of total and legal-sized P. argus during visual surveys by 3 divers in marine reserves before vs. after the $2 \mathrm{~d}$ sport diver mini-season in 2005 and 2007 . The average area searched in each reserve was $760 \mathrm{~m}^{2}$

\begin{tabular}{|c|c|c|c|c|c|c|c|c|}
\hline \multirow[t]{3}{*}{ Reserve } & \multicolumn{4}{|c|}{ Total lobsters } & \multicolumn{4}{|c|}{ Legal lobsters } \\
\hline & \multicolumn{2}{|c|}{ Before } & \multicolumn{2}{|c|}{ After } & \multicolumn{2}{|c|}{ Before } & \multicolumn{2}{|c|}{ After } \\
\hline & No. & Density & No. & Density & No. & Density & No. & Density \\
\hline \multicolumn{9}{|l|}{2005} \\
\hline Sand Key & 0 & 0 & 4 & 0.002 & 0 & 0 & 2 & 0.002 \\
\hline Rock Key & 2 & 0.001 & 7 & 0.005 & 2 & 0.001 & 6 & 0.004 \\
\hline Eastern Dry Rocks & 0 & 0 & 4 & 0.003 & 0 & 0 & 2 & 0.001 \\
\hline Western Sambo & 28 & 0.012 & 49 & 0.025 & 18 & 0.008 & 30 & 0.015 \\
\hline Eastern Sambo & 28 & 0.028 & 38 & 0.031 & 23 & 0.020 & 25 & 0.023 \\
\hline Looe Key & 2 & 0.001 & 3 & 0.002 & 2 & 0.001 & 2 & 0.001 \\
\hline \multicolumn{9}{|l|}{2007} \\
\hline Sand Key & 0 & 0 & 0 & 0 & 6 & 0.005 & 0 & 0 \\
\hline Rock Key & 7 & 0.004 & 15 & 0.010 & 5 & 0.003 & 15 & 0.010 \\
\hline Eastern Dry Rocks & 3 & 0.002 & 7 & 0.004 & 1 & 0.001 & 1 & 0.001 \\
\hline Western Sambo & 72 & 0.020 & 79 & 0.023 & 39 & 0.017 & 65 & 0.018 \\
\hline Eastern Sambo & 8 & 0.005 & 15 & 0.014 & 5 & 0.009 & 15 & 0.004 \\
\hline Looe Key (not sampled) & - & - & - & - & - & - & - & - \\
\hline
\end{tabular}

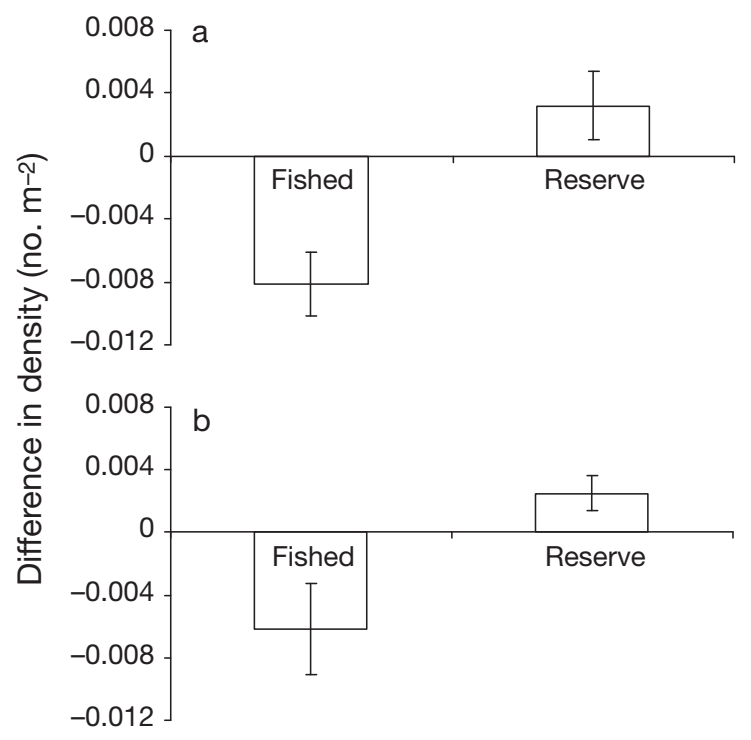

Fishing Status

Fig. 2. Panulirus argus. Mean (+ SE) change in density of (a) total lobsters and (b) legal-sized (>76 mm carapace length) lobsters from before to after the $2 \mathrm{~d}$ mini-season in fished sites and marine reserves closed to fishing. See 'Results' for statistical values

reserves by 3 divers on a given site ranged from 0 at Sand Key in 2005 and 2007, to 79 at Western Sambo after the $2 \mathrm{~d}$ mini-season in 2007 (Table 1). The lowest lobster densities occurred at the 3 sites farthest from Key West (Sand Key, Rock Key, Eastern Dry Rocks), whereas the highest densities occurred at the sites closest to Key West (Western Sambo, Eastern Sambo) (Table 1, Fig. 1), possibly due to closer proximity of backreef nursery habitats in the latter. Lobsters disturbed by sport divers during the $2 \mathrm{~d}$ mini-season migrated to marine reserves, especially those containing relatively high densities of conspecifics. The change in mean density of spiny lobsters from before to after the fishing season ranged from a low of $0 \%$ for legal lobsters in Eastern Dry Rocks in 2007 to a high of $51 \%$ for legal lobsters at Western Sambo in 2005 (Table 1). These changes were significantly lower than 0 for reefs open to fishing $(t=-4.78, \mathrm{df}=1,6, \mathrm{p}<0.005)$, and significantly higher than 0 for reefs in reserves closed to fishing ( $t=4.03, \mathrm{df}=1,6, \mathrm{p}<0.01)$ (Fig. 2). For 2005 and 2007, there was a positive, statistically significant, density-dependent relationship between the increase in density of total and legal lobsters from before to after the $2 \mathrm{~d}$ mini-season in reserves (Fig. 3), and the density of lobsters within a reserve just prior to the mini-season (non-linear, polynomial regression: total lobsters: $\mathrm{r}^{2}=0.83, \mathrm{df}=3,11, \mathrm{p}=0.001$; legal lobsters: $\mathrm{r}^{2}=0.79, \mathrm{df}=3,11, \mathrm{p}=0.002$ ).

\section{DISCUSSION}

The present study provides experimental evidence that mobile animals can migrate into marine reserves in response to fishery disturbance, which may explain the sometimes rapid build-up of animals in reserves (Sobel \& Dahlgren 2004). At the scale of marine reserves and fished areas in the Florida Keys, the density of spiny lobsters in the present study decreased significantly in fished areas from before to after a $2 \mathrm{~d}$ sport diver mini-season, whereas lobster density increased significantly in marine reserves, particularly 


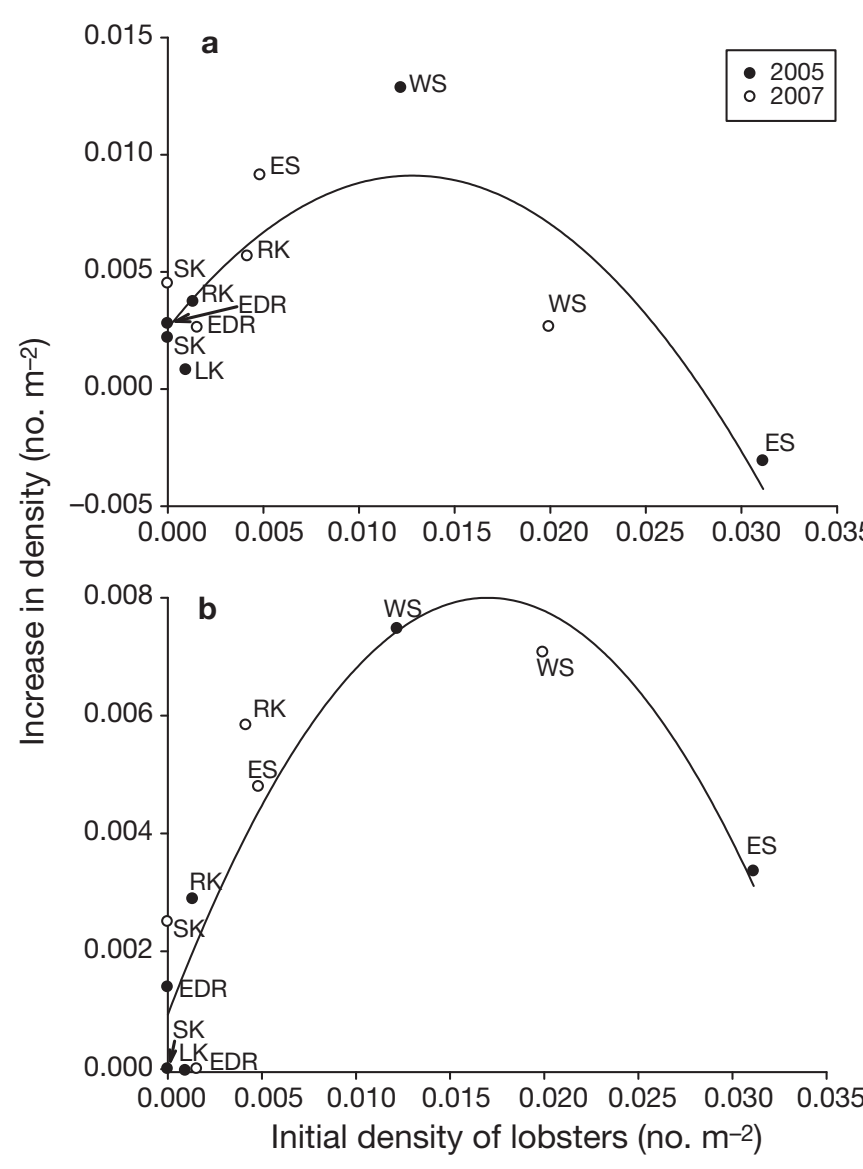

Fig. 3. Panulirus argus. The relationship between density of lobsters in reserves just prior to the $2 \mathrm{~d}$ mini-season, and the observed increase in lobster density following the fishing season in 2005 and 2007. (a) Total lobsters and (b) legal-sized (>76 mm carapace length) lobsters. SK = Sand Key, LK = Looe Key, EDR = Eastern Dry Rocks, RK = Rock Key, WS = Western Sambo, ES = Eastern Sambo. See Table 1 for means and counts, and 'Results' for statistical values

those with high densities of lobster. While this process may be a result of either random post-disturbance redispersion or a non-random mechanism that does not rely on olfaction, the volume-dependent, conspecific guide effect for Panulirus argus (Ratchford \& Eggleston 1998, Childress \& Herrnkind 2001) likely influences the habitat choice of disturbed lobsters, potentially guiding them to areas of abundant non-disturbed lobsters in marine reserves after nocturnal foraging and movements.

For 3 reasons, the term 'spill-in' is used in the present study to describe the observed migration of disturbed lobsters to reserves containing relatively high densities of undisturbed lobsters. (1) Spill-in implies an active behavioral mechanism (although we recognize the alternative random mechanism above) that appears to be dependent upon the density of non-disturbed conspecifics within a reserve. This is analogous to spillover, also a density-dependent process that may be active or passive involving the movement of animals from high densities in reserves to low densities in adjacent fished areas. In this case, spill-in increases with densities of conspecifics. (2) The concept of spillin not only applies to other species of lobster that may be gregarious (see below), but to other mobile species that exhibit nocturnal group migrations such as Haemulid fish that migrate off-reef at night as a school and back to coral reefs at dawn (Helfman et al. 1982), as well as terrestrial taxa. For example, diurnal foraging by birds and baboons away from refuge areas is followed by their return at night (Cohen 1972, Krebs \& Davies 1984), which may provide a mechanism for spill-in to terrestrial reserves where disturbance, such as human development activities, is relatively low inside compared to outside a reserve. (3) The term spill-in is a concise term and a 'sticky' idea (i.e. it is easily remembered) that simplifies and facilitates communication of this phenomenon once it has been defined, as above.

It is unclear how long the build-up of lobsters in reserves persists after the $2 \mathrm{~d}$ sport diver mini-season ends. At annual scales, the mean size and abundance of Panulirus argus in the relatively large Western Sambo reserve has increased steadily since full protection was implemented in 1997 (Cox \& Hunt 2005). At monthly time scales, surveys of the percentage of legal-sized $P$. argus in Western Sambo versus fished areas were unchanged from before the fishing season began in July to after the fishing season in September (Cox \& Hunt 2005). This suggests that the disturbanceinduced build-up of $P$. argus observed in marine reserves during the $2 \mathrm{~d}$ mini-season in the present study may persist for $\geq 1$ mo. The persistence of any build-up of $P$. argus during the mini-season in reserves is likely dependent upon the size of the reserve. For example, although the abundance of $P$. argus on patch reefs in the Looe Key marine reserve increased from the closed to the open fishing season, similar to the spill-in effect reported in the present study, only $4 \%$ of tagged lobsters remained within this relatively small reserve (50 ha) over a 9 to 12 mo period (Hunt et al. 1991). Conversely, relatively large resident populations of $P$. argus have become established in the relatively large Western Sambo (3000 ha) and Dry Tortugas marine reserves ( 51 000 ha) (Davis 1977, Cox \& Hunt 2005). Even if this spill-in effect is relatively short-lived (<1 mo), such a refuge from fishing is critically important because (1) the majority of fishing effort and landings occurs during the first month of the lobster fishing season (Hunt et al. 1999), and (2) lobsters that avoid harvest in one season are free to grow and reproduce until the fishing season begins in July of 
the following year (Cox \& Hunt 2005). Furthermore, temporary protection of highly mobile species in reserves can result in enhanced population fecundity (Sladek-Nowlis \& Roberts 1999).

The implications of the present study for reserve design are varied and depend on the management goal of a given reserve. In addition to locating reserves in the best available habitat, locating reserves along migratory routes of mobile species that migrate in response to disturbances such as fishing or habitat degradation would presumably enhance reserve populations and provide a refuge from fishing. Therefore, risk-averse fishery management strategies might locate reserves adjacent to intensely fished areas to enhance spill-in of mobile species.

There are other ecological processes that might cause the build-up of Panulirus argus in marine reserves, including spatial variation in recruitment events that happen to match the spatial distribution of reserves, and normal ontogenetic habitat shifts that occur in phase with the $2 \mathrm{~d}$ mini-season (see Cox \& Hunt 2005). These recruitment and ontogenetic habitat shift processes, however, are unlikely to explain the rapid build-up of $P$. argus in reserves in the present study because it occurred over such a short period of time.

The reduced lobster spill-in observed at the highest lobster density in a marine reserve in the present study (Eastern Sambo in 2005, Fig. 3b) suggests that marine reserves may become saturated with lobsters at high densities, although it is possible that this data point represents higher variation at higher lobster densities in reserves. A possibility exists that animals that emigrate from a disturbance would simply move randomly until the frequency of disturbance in a given habitat (e.g. a reserve) drops below some threshold level, at which point the animal stays. This 'passive' accumulation mechanism could account for the build-up of animals in certain habitats (e.g. reserves) but would occur at a slower rate relative to a 'guided' accumulation affect. This may or may not explain rapid increases in lobster abundance observed over a period of days, as was the case in the present study. Another potential explanation may relate to habitat quality. The reserves surveyed in the present study were intentionally placed in areas of good habitat quality, with extensive coral reefs of high structural complexity. If lobsters were randomly redistributing themselves after a disturbance event, habitat quality could be another potential guide and/or cue to an appropriate refuge. If this strategy could successfully be employed it remains unclear as to why lobsters would restrict its use to after disturbance events (densities of lobsters were similar between reserve and non-reserve sites before the fishing season began).
Gregarious sheltering behavior and nocturnal foraging is common in lobsters of the family Palinuridae, which span all of the tropical oceans, and include Panulirus argus, P. cygnus, P. interruptus, P. ornatus, P. elephas, as well as the temperate species Jasus edwarsii (Lipcius \& Eggleston 2000). P. argus, P. elephas and $J$. edwardsii have all shown relatively rapid positive responses to the creation of marine reserves (Kelly et al. 2000, Cox \& Hunt 2005, Goni et al. 2006), which may be caused, in part, by density-dependent spill-in. Although spill-in to reserves may facilitate a rapid refuge from fishing pressure, density-dependent spill-in could also exacerbate the spread of diseases, parasites, and exotic species. For example, density-dependent spill-in for $P$. argus could exacerbate the spread of a lethal virus identified in this species (Behringer et al. 2006).

Spill-in of Caribbean spiny lobster to marine reserves following diver disturbance has potential implications regarding the function and conservation benefits of marine reserves. One of the most striking and likely controversial implications is how spill-in might alter a key benefit of reserves to adjacent fisheries-spillover of juveniles and adults. Relatively rapid migration of mobile fishery species into reserves would theoretically reduce their availability to fishers outside of reserves, potentially leading to short-term reductions in catch. But, as spillover is a densitydependent process, any mechanism that results in higher abundances of fishery species inside a reserve is likely to decrease the time required before spillover occurs, thereby increasing the amount of biomass emigrating from the reserve. Therefore, spill-in and spillover may potentially act in tandem, protecting fishery target species when disturbance is high, while also making them available to the fishery through both disturbance-mediated spill-in and natural reserve recovery. Although this hypothesis remains to be tested, Leeworthy et al. (2004) determined that shortly after the Western Sambo reserve was established in the Florida Keys there were no detrimental impacts to the local lobster fishery adjacent to the reserve, apparently because lobsters had a chance to molt before migrating out of reserves and being captured.

Ours is not the first study to report movement into marine reserves, nor demonstrate attraction to habitats via cueing on conspecifics. For example, gregarious and acoustically active (via swim bladder 'beating') black drum Pogonias cromis showed greater immigration into marine reserves near Cape Canaveral, Florida, than export, although it was unclear if the mechanism was acoustic attraction to large schools within the reserve, statistical chance, or a one-tailed bias problem in which exported, tagged fish were caught by recreational fishers but not fully reported (Tremain et al. 2004). In terrestrial systems, empirical 
studies and results from metapopulation computer simulation modeling have documented conspecific attraction and demonstrated how conspecific attraction lowers the proportion of occupied habitat patches within equilibrium metapopulations, respectively (Smith \& Peacock 1990, Ray et al. 1991).

The potential for disturbance to mediate a build-up of abundance within reserves, in a spill-in-like fashion, is unlikely to be constrained to the example described in the present study. In the marine environment, animals are likely to respond to disturbance from a range of activities including catch and release fisheries, escapement and/or avoidance of trawl and other net fisheries, displacement as a result of seabed damage caused by contact fishing gears such as dredges, and undersized animals that are released from pots, lines or nets. Many of these animals will have some level of social interaction and some form of communication (e.g. visual signals, acoustic production, or specific olfactory signals) that could also facilitate a spill-in response. Therefore, the potential for spill-in to apply to different species in other reserves is likely high.

In conclusion, conspecific attraction of disturbed animals that increases with the density of non-disturbed animals should be considered in movement models and studies of habitat shifts of mobile species. This is because of the potentially strong effect it has on animal behavior, and its potential to modify estimates of animal colonization and subsequent abundance and mortality rates within reserves (e.g. Gerber et al. 2005). The disturbance-induced migration of Panulirus argus (spill-in) identified in the present study provides an alternative mechanism to spillover regarding the function of reserves. Further research that could stem from these results will contribute to a better understanding of how mobile, gregarious organisms inhabiting both marine and terrestrial systems, such as those that form flocks, schools, herds, troops, or packs, respond to the interplay between human disturbance and the reserves intended to protect them.

Acknowledgements. We thank C. Birkeland and 2 anonymous reviewers for constructive comments that greatly improved the manuscript. Funding was provided by The Ocean Conservancy and US Fish and Wildlife Service (Contract no. 1448-40181-99-6), the National Fish and Wildlife Foundation (2004-0011-023), and the Fund for Sustainable Fisheries, North Carolina State University. This research was carried out with a research and education permit from the Florida Keys National Marine Sanctuary Program (FKNMS2002-061 \& FKNMS-2007-070). Thanks to G. Bell, L. Cox, G. Plaia and J. VanderPluym for assisting with lobster data collection.

\section{LITERATURE CITED}

Alcala AC, Russ GR, Maypa AP, Calumpong HP (2005) A long-term, spatially replicated experimental test of the effect of marine reserves on local fish yields. Can J Fish Aquat Sci 62:98-108

Behringer DC, Butler MJ, Shields JD (2006) Avoidance of disease by social lobsters. Nature 441:421

Childress MJ, Herrnkind WF (2001) The guide effect influence on the gregariousness of juvenile Caribbean spiny lobsters. Anim Behav 62:465-472

Cohen JE (1972) Markov population processes as models of primate social and population dynamics. Theor Popul Biol 3:119-134

> Cox C, Hunt JH (2005) Change in size and abundance of Caribbean spiny lobsters Panulirus argus in a marine reserve in the Florida Keys National Marine Sanctuary, USA. Mar Ecol Prog Ser 294:227-239

Cox C, Hunt JH, Lyons WG, Davis G (1997) Nocturnal foraging of the Caribbean spiny lobster (Panulirus argus) on offshore reefs of Florida. Mar Freshw Res 48:671-679

Davis GE (1977) Effects of recreational harvest on a spiny lobster, Panulirus argus, population. Bull Mar Sci 27:223-236

Davis GE (1981) Effects of injuries on spiny lobster, Panulirus argus, and implications for management. Fish Bull US 78: 979-984

- Eggleston DB, Lipcius RN (1992) Shelter selection by spiny lobster under variable predation risk, social conditions and shelter size. Ecology 73:992-1011

Eggleston DB, Johnson EG, Kellison GT, Nadeau DA (2003) Intense removal and non-saturating functional responses by recreational divers on spiny lobster Panulirus argus. Mar Ecol Prog Ser 257:197-207

Eggleston DB, Dahlgren CP, Johnson EG (2004) Fish density, diversity and size-structure within multiple back-reef habitats of Key West National Wildlife Refuge, USA. Bull Mar Sci 75:175-204

Eggleston DB, Parsons DM, Kellison GT, Plaia GR, Johnson EG (2008) Functional response of sport divers to lobsters with application to fisheries management. Ecol Appl 18: 258-272

> Gerber LR, Heppell SS, Ballantyne F, Sala E (2005) The role of dispersal and demography in determining the efficacy of marine reserves. Can J Fish Aquat Sci 62:863-871

Goñi R, Quetglas A, Reñones O (2006) Spillover of spiny lobsters Panulirus elephas from a marine reserve to an adjoining fishery. Mar Ecol Prog Ser 308:207-219

Helfman GS, Meyer JL, McFarland WN (1982) The ontogeny of twilight migration patterns in grunts (Pisces: Haemulidae). Anim Behav 30:317-326

Herrnkind WF, Vanderwalker J, Barr L (1975) Population dynamics, ecology and behavior of spiny lobsters of St. John, USVI. VI. Habitation, patterns of movement, and general behavior. Sci Bull Mus Nat Hist L A 20:31-45

Hunt JH, Matthews TR, Forcucci D, Hedin B, Bertelsen RD (1991) Management implications of trends in the population dynamics of the Caribbean spiny lobster, Panulirus argus, at Looe Key National Marine Sanctuary. Final Report to NOAA, Florida Marine Research Institute, Marathon, FL

Hunt JH, Sharp WC, Matthews TR, Muller RG, Bertelsen RD, Cox C (1999) Status of the spiny lobster fishery in Florida, 1999. Report to the Florida Fish and Wildlife Conservation Commission. Florida Marine Research Institute, Marathon, FL

> Kelly S, Scott D, MacDiarmid AB, Babcock RC (2000) Spiny lobster, Jasus edwardsii, recovery in New Zealand marine reserves. Biol Conserv 92:359-369

Krebs JR, Davies NB (eds) (1984) Behavioural ecology: an evolutionary approach. Blackwell Scientific Publications, Oxford 
Leeworthy VR, Wiley PC, Hospital JD (2004) Importancesatisfaction ratings five-year comparison, SPA \& ER use, and socioeconomic and ecological monitoring comparison results 1995-96 to 2000-01. National Ocean Service, Special Projects, Silver Spring, MD

Lipcius RN, Eggleston DB (2000) Introduction: ecology and fishery biology of spiny lobsters. In: Phillips BF, Kittaka J (eds) Spiny lobsters: fisheries and culture, 2nd edn. Fishing News Books, Blackwell Science, Oxford, p 1-41

National Research Council (NRC) (2001) Marine protected areas: tools for sustaining ocean ecosystems. National Academy Press, Washington, DC

Parsons DM, Eggleston DB (2005) Indirect effects of recreational fishing on behavior of the spiny lobster Panulirus argus. Mar Ecol Prog Ser 303:235-244

Parsons DM, Eggleston DB (2006) Human disturbance, natural predators and unobserved mortality in a spiny lobster, Panulirus argus, fishery. J Exp Mar Biol Ecol 334: 196-205

PDT (Plan Development Team) (1990) The potential of marine fisheries reserves for reef management in the US southern Atlantic. Snapper-grouper Plan Development Team report for the South Atlantic Fishery Management Council

Editorial responsibility: Charles Birkeland, Honolulu, Hawaii, USA
(Bohnsack JA, subcommittee chair). NOAA Tech Memo NMFS-SEFC-261

Ratchford SG, Eggleston DB (1998) Size- and scaledependent chemical attraction contributes to an ontogenetic shift in sociality. Anim Behav 56:1027-1034

Ratchford SG, Eggleston DB (2000) Temporal shift in the release of a chemical attractant contributes to a diel shift in sociality. Anim Behav 59:793-799

Ray C, Gilpin M, Smith AT (1991) The effect of conspecific attraction on metapopulation dynamics. Biol J Linn Soc 42:123-134

> Russ GR, Alcala AC, Maypa AP, Calumpong HP (2004) Marine reserve benefits local fisheries. Ecol Appl 14:597-606

Sladek-Nowlis J, Roberts CM (1999) Fisheries benefits and optimal design of marine reserves. Fish Bull 97:604-616

Smith AT, Peacock MM (1990) Conspecific attraction and the determination of metapopulation colonization rates. Conserv Biol 4:320-323

Sobel J, Dahlgren CP (2004) Marine reserves: a guide to science, design and use. Island Press, Washington, DC

Tremain DM, Harden CW, Adams DH (2004) Multidirectional movements of sportfish species between an estuarine notake zone and surrounding waters of the Indian River Lagoon, Florida. Fish Bull 102:533-544

Submitted: October 26, 2007; Accepted: August 14, 2008 Proofs received from author(s): November 12, 2008 